\title{
Chapter 12 \\ The Role of Microorganisms in the Removal of Nitrates and Sulfates on Artistic Stoneworks
}

\author{
Giancarlo Ranalli and Elisabetta Zanardini
}

\begin{abstract}
This chapter will focus on the role of microorganisms in the removal of nitrates and sulfates on artistic stoneworks. The main groups of microbes and their metabolisms involved in bioremoval methods for the preservation and protection of cultural artifacts are reported. The aim is to offer a comprehensive view on the role and potentiality of virtuous microorganisms in the biocleaning and bioremoval of black crusts and salts altering $\mathrm{CH}$ stoneworks. We highlight the importance of the use of the selected microorganisms and the adoption of adequate carriers for the anaerobic metabolism of nitrate and sulfate reducers to be applied on the altered stone surfaces. The following characteristics of the delivery system are of great importance: the ability to guarantee water content for microbes, the absence of toxicity for the environment, no negative effects to the stone surfaces, easy to prepare, to apply, and to remove from different stone surfaces at the end of the treatment. We report an overview of the last 30 years on the biocleaning processes including diagnostic studies of the alterations, the assessment of associated risks, the effectiveness and efficacy of the proposed method, and the evaluation in terms of economic and environmental sustainability.
\end{abstract}

Keywords Cultural Heritage $\cdot$ Biocleaning $\cdot$ Black crust $\cdot$ Nitrates $\cdot$ Sulfates · Biotechnology $\cdot$ Bacteria

It is well known that microorganisms have a crucial role in their natural habitats being involved in the biogeochemical cycles and in the transformation of inorganic and organic compounds as energy and carbon sources. However, in the Cultural

\footnotetext{
G. Ranalli $(\bowtie)$

Department of Biosciences and Territory, University of Molise, Pesche, Italy

e-mail: ranalli@unimol.it

E. Zanardini

Department of Sciences and High Technology, University of Insubria, Como, Italy

e-mail: elisabetta.zanardini@uninsubria.it 
Heritage $(\mathrm{CH})$ field microorganisms have a double role in relation to the biodeterioration processes and the biorecovery potentialities.

In this chapter, we briefly describe the role of microorganisms in the biodeterioration of stoneworks and, in particular, we focus the attention on the use of viable bacterial cells for the removal of nitrates and sulfates from $\mathrm{CH}$ altered stone surfaces.

Outdoor archeological and monumental $\mathrm{CH}$ stoneworks are subjected to deterioration damages due to physical, chemical, and biological processes causing structural, mechanical, chemical, and aesthetic alterations of the original material and leading to stone decay (Sorlini et al. 1987; Ortega-Calvo et al. 1995; Mansch and Bock 1998; McNamara and Mitchell 2005; Gorbushina 2007; Pinna and Salvadori 2008; Ranalli et al. 2009; Scheerer et al. 2009; May 2010).

Climate change can indirectly affect stone deterioration due to fluctuation of temperature, rainfall and humidity determining higher salt crystallization processes (Brimblecombe and Grossi 2007; Grossi et al. 2007; Duthie et al. 2008).

Salts, deriving from various sources (e.g., air pollution, soil, wind from the sea or the desert, de-icing salt, cleaning materials, garden fertilizers, etc.) can seriously damage the $\mathrm{CH}$ stone surfaces due to the stresses generated by crystal growth in the stone pores (Scherer 2000; Doehne and Price 2010).

All the deterioration processes depend on the stone physical and chemical properties since different lithotypes have diverse strength, porosity, hardness, absorption, etc. These aspects strongly affect the decay of monuments and building materials and can also favor the surface colonization of microorganisms and this concept is named bioreceptivity (Viles and Moses 1998; Herrera and Videla 2009; Doehne and Price 2010). Indeed, together with physical and chemical agents, biological agents are also important in the deterioration of historical and artistic stoneworks acting in different ways: mechanically, chemically, and aesthetically (Warscheid and Braams 2000; Dornieden et al. 2000; Saiz-Jimenez 2001; Ranalli et al. 2009; Bhatnagar et al. 2010; Zanardini et al. 2011, 2016, 2019; De Leo et al. 2012).

The growth of the biodeteriogens on stone mainly occurs with the formation of biofilm that can produce mechanical stresses to the mineral structure leading to changes in the stone pore size and in the moisture circulation patterns and temperature response (Gorbushina 2007). However, it has also evidenced that biological patinas and biofilms in some situations do not cause stone decay but can act as a protective layer of the stone surfaces (Caneva et al. 2008; De Muynck et al. 2010).

Among the principal groups of microorganisms involved in $\mathrm{CH}$ biodeterioration processes, diverse bacteria have been detected and isolated from altered stonework surface and/or at the depth of few millimeters; chemolithoautotrophs such as bacteria involved in sulfur and nitrogen cycles that can strongly acidify by the production of inorganic acid (sulfuric and nitric acids, respectively). In the past, great attention was focused on acidifying bacteria such as sulfur oxidizers (Thiobacillus spp.) and nitrifiers (Nitrosomonas spp.) which can cause the transformation of calcium carbonate giving calcium sulfate and calcium nitrate leading to material corrosion (Mansch and Bock 1998; Tiano et al. 1999, 2006; Abeliovich 2006). 


\section{Stone Sulfation and Nitration Mechanisms}

Air pollution has been recognized in numerous studies as a strong factor involved in the outdoor stoneworks deterioration for causing material transformation and surface deposits (Camuffo 1998; Warscheid and Braams 2000; Zanardini et al. 2000; SaizJimenez 2003; Doehne and Price 2010). Inorganic atmospheric pollutants such as air sulfur oxides $\left(\mathrm{SO}_{2}\right.$ and $\left.\mathrm{SO}_{3}\right)$, nitrogen oxides $\left(\mathrm{NO}_{\mathrm{x}}\right)$, and carbon oxides, in the presence of water, produce acidic solutions, which react with the calcareous materials and transform calcium carbonate into calcium sulfate dihydrate and calcium nitrate giving consequently decay phenomena of "sulfation" and "nitration" and the formation of damaging crusts namely "black crust" (Gauri et al. 1989; Rivadeneyra et al. 1991, 1994; Orial et al. 1992; Salvadori and Realini 1996; Saiz-Jimenez 2003, 2004; Doehne and Price 2010).

In the case of the black crust formation, the main mechanism is the sulfation reaction involving calcium carbonate as reported below:

$$
\begin{aligned}
& 2 \mathrm{SO}_{2}+\mathrm{O}_{2} \rightarrow 2 \mathrm{SO}_{3} \\
& \mathrm{SO}_{3}+\mathrm{H}_{2} \mathrm{O} \rightarrow \mathrm{H}_{2} \mathrm{SO}_{4} \\
& \mathrm{H}_{2} \mathrm{SO}_{4}+\mathrm{CaCO}_{3} \rightarrow \mathrm{CaSO}_{4} .\left(2 \mathrm{H}_{2} \mathrm{O}\right)+\mathrm{CO}_{2}
\end{aligned}
$$

The corrosion processes operated by acidic pollutants on stone can differently happen based on the environment where monuments are located: exposed and sheltered areas can show in fact different levels of stone surfaces deterioration. When the products from chemical reactions can accumulate, black crusts on stone surfaces are often formed and the blackness mainly depends on the air pollutants from fossil fuel combustion, while in exposed areas the rainfall normally inhibits the formation of these kinds of alterations as shown in Fig. 12.1a and b. (Doehne and Price 2010).
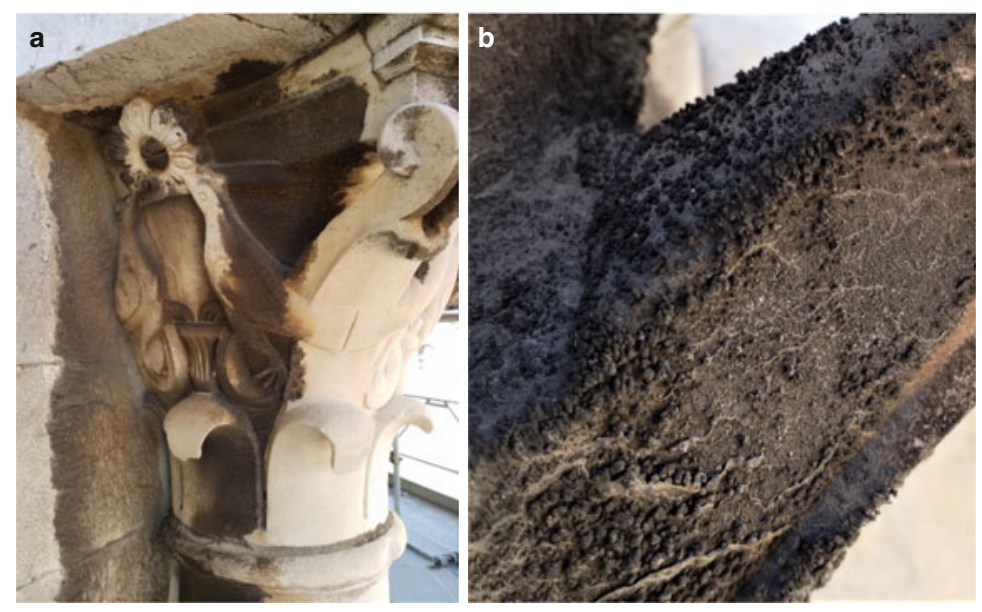

Fig. 12.1 (a-b) Typical black crusts on ancient altered marble by exposition to outdoor conditions, at Pisa Cathedral (Credits: Photos by OpaPisa) 
Restoration practices, aiming the cleaning of altered stone surfaces, need to previously define and characterize the stone mineralogical properties and the level and extend of decay in order to understand the causes and mechanisms of the processes actually in place. Preservation and conservation of $\mathrm{CH}$ stoneworks is not simple, as material decay is a natural process, and, therefore, can be only slowed down (Fassina 1994).

Therefore, the conservation of stone surfaces needs a technical and scientific approach. As we said above, outdoor stone surfaces accumulate different kinds of materials, i.e. atmospheric pollutants, salts and residues from past restorative interventions giving the formation of surface deposits.

In the case of the black crusts, stone surfaces appear extremely damaged in their aesthetic, chemical, and physical aspects; furthermore, stone properties are also affected with the formation of fissures, fractures, exfoliation, disintegration up to loss of original material.

\section{Removal of Black Crusts, Sulfates, Nitrates, and Deposits}

The removal of these kinds of alteration is a serious issue for the conservatorsrestorers and the different treatments aim to be not too much aggressive and to avoid the alteration of the original stone surfaces.

The first step is the accurate characterization of the materials (diagnosis) that must be removed and the conservation state of the stoneworks followed by the individualization of the best methodology to use, showing high efficiency, selective cleaning, absence of aesthetic alteration, and durability (Vergès-Belmin 1996; Gulotta et al. 2014).

Conventional cleaning methods are mechanical (brushing and rubbing, washing and steaming, wet and dry abrasives, etc.) and chemical (alkaline treatments, acidic treatments, or organic solvents, etc.). These methods can be too aggressive and not selective and therefore the effort to find an alternative has been recognized as a priority.

Methodologies based on laser and biological cleaning can give a relevant contribution in the treatment of such stone alterations (Ramirez et al. 2005; Doehne and Price 2010; Junier and Joseph 2017). Lasers can discriminate between the soiling and the substratum, are less intrusive, more easily controlled, allowing a cleaning method with high selectivity. In some cases, the use of laser does not permit the complete removal of the deposits and can cause color changes. Moreover, studies report problems in the treatment of polychrome sculptures and in the use of laser on large superficial areas since the cost considerably increases (Salimbeni et al. 2003).

Until now, we cited the conventional cleaning methods, considering the following definition of the term cleaning reported in EWAGLOS project book: "Action performed to remove dirt deposits, foreign matters and products of alteration present on artworks surface that can be a source of decay or deterioration or aesthetic disturbance" (EWAGLOS 2016). The main cleaning techniques are 
mechanical, physico-chemical and also biological; the last (the biocleaning) includes the use of living organisms and/or the enzymes as cleaning agents by controlled reproduction of their metabolic processes.

The biological methods based on the use of microorganisms and enzymes as cleaning agents in the "biorestoration" of artworks represented in the last decades an attractive alternative to the mechanical and chemical methods (Bellucci et al. 1999; Cremonesi 1999). The key idea of using living cells in the conservation and preservation of works of art is supported by the fact that microorganisms (mainly bacteria) are the most versatile and ubiquitous organisms found on earth, and they are able of colonizing almost any environment (Maier et al. 2000; Sorlini and Cappitelli 2008).

Even if we know that some microorganisms have "negative effects," many of them are responsible for "positive effects" such as the degradation and transformation processes of pollutants (Sorlini et al. 1987).

The microorganisms involved in the biorestoration can be isolated from natural environments (soil, water, etc.) and/or selected among the autochthonous microbial communities inhabiting historical artworks. Once verified their ability in the removal of the undesired substances, after an adequate increased cellular biomass, they can be used in the recovery applications (bioaugmentation) showing in this case not a negative factor, but a new and positive conservation perspective.

Therefore, the methods based on the use of specific microorganisms can positively help in the cleaning of stone surfaces exploiting the microbial versatility, their different metabolic activities and role in the biogeochemical cycles in their natural habitat. (Atlas et al. 1988; Ranalli et al. 2003). Safe living microbial cells under optimal controlled conditions reproduce the same processes that occur in nature, softly remove certain substances and represent an eco-friendly solution without health risks for the conservator-restorers and the environment (Boquet et al. 1973; Atlas et al. 1988; Ferrer et al. 1988; Heselmeyer et al. 1991; Saiz-Jimenez 1997; Castanier et al. 2000; Maier et al. 2000; Rodriguez-Navarro et al. 2000; Ranalli et al. 2003, 2005; Tiano et al. 2006; Biavati and Sorlini 2008; Valentini et al. 2010; Sasso et al. 2015).

In the last decades biocleaning technologies have been applied in the removal of organic and inorganic unwanted substances on $\mathrm{CH}$ stone surfaces (marble, tuff, sandstone, limestone, etc.), on ceramic material (brick-work), on paper materials, and on concrete using specific bioformulations containing Desulfovibrio sp. and Pseudomonas sp. cells (Gauri et al. 1989, 1992; Heselmeyer et al. 1991; Delgado Rodrigues and Valero 2003; Ranalli et al. 2005; De Graef et al. 2005; De Belie et al. 2005; Cappitelli et al. 2006, 2007; Alfano et al. 2011; Gioventù et al. 2011; Barbabietola et al. 2012; Troiano et al. 2013).

Table 12.1 reports the biotreatment studies carried out specifically for the removal of salts from $\mathrm{CH}$ stoneworks, together with the bacterial strains and the delivery systems adopted.

Sulfate and nitrate reducers (see Prokaryotes organisms involved in sulfur and nitrogen cycles and reported in Table $12.2 \mathrm{a}$ and $\mathrm{b}$ ) have been used for the removal of 
Table 12.1 Biotreatment studies carried out specifically for the removal of salts from $\mathrm{CH}$ stoneworks

\begin{tabular}{|c|c|c|c|c|}
\hline $\begin{array}{l}\text { Main decay } \\
\text { agents }\end{array}$ & Type of materials & Biocleaning bacteria & $\begin{array}{l}\text { Delivery } \\
\text { systems }\end{array}$ & References \\
\hline \multirow[t]{3}{*}{ Sulfates } & $\begin{array}{l}\text { Marble (Georgia) stone } \\
\text { and statue }\end{array}$ & $\begin{array}{l}\text { Desulfovibrio } \\
\text { desulfuricans (An) }\end{array}$ & Immersion & $\begin{array}{l}\text { Gauri et al. } \\
(1989,1992)\end{array}$ \\
\hline & Marble and sandstone & D. vulgaris (An) & Immersion & $\begin{array}{l}\text { Heselmeyer } \\
\text { et al. (1991) }\end{array}$ \\
\hline & Marble & $\begin{array}{l}\text { D. desulfuricans, } \\
\text { (An) } \\
\text { D. vulgaris (An) }\end{array}$ & Sepiolite & $\begin{array}{l}\text { Ranalli et al. } \\
(1996,1997)\end{array}$ \\
\hline \multirow[t]{4}{*}{ Black crusts } & $\begin{array}{l}\text { Marble (Candoglia } \\
\text { stone), Milan }\end{array}$ & $\begin{array}{l}\text { D. vulgaris subsp. } \\
\text { vulgaris (An) }\end{array}$ & $\begin{array}{l}\text { Sepiolite } \\
\text { Hydrobiogel } \\
97\end{array}$ & $\begin{array}{l}\text { Cappitelli } \\
\text { et al. (2005) }\end{array}$ \\
\hline & $\begin{array}{l}\text { Marble sculpture, } \\
\text { Milan }\end{array}$ & $\begin{array}{l}\text { D. vulgaris subsp. } \\
\text { vulgaris (An) }\end{array}$ & Carbogel & $\begin{array}{l}\text { Cappitelli } \\
\text { et al. (2006) }\end{array}$ \\
\hline & $\begin{array}{l}\text { Limestone sculpture, } \\
\text { Trento }\end{array}$ & $\begin{array}{l}\text { D. vulgaris subsp. } \\
\text { vulgaris (An) }\end{array}$ & Carbogel & $\begin{array}{l}\text { Polo et al. } \\
\text { (2010) }\end{array}$ \\
\hline & $\begin{array}{l}\text { Colored lithotypes, } \\
\text { Firenze }\end{array}$ & $\begin{array}{l}\text { D. vulgaris subsp. } \\
\text { vulgaris (An) }\end{array}$ & Carbogel & $\begin{array}{l}\text { Gioventù } \\
\text { et al. (2011) }\end{array}$ \\
\hline $\begin{array}{l}\text { Black crusts } \\
\text { and grey } \\
\text { deposits }\end{array}$ & $\begin{array}{l}\text { Marble column and } \\
\text { statue, Cemetery of } \\
\text { Milan }\end{array}$ & $\begin{array}{l}\text { D. vulgaris subsp. } \\
\text { vulgaris (An) }\end{array}$ & Arbocel & $\begin{array}{l}\text { Troiano et al. } \\
\text { (2013) }\end{array}$ \\
\hline \multirow[t]{2}{*}{ Nitrates } & $\begin{array}{l}\text { Brickworks and calcar- } \\
\text { eous stones, (marble } \\
\text { and Vicenza stones) }\end{array}$ & $\begin{array}{l}\text { Pseudomonas stutzeri } \\
(\mathrm{Ae})\end{array}$ & Sepiolite & $\begin{array}{l}\text { Ranalli et al. } \\
\text { (1996) }\end{array}$ \\
\hline & $\begin{array}{l}\text { Sandstone walls, } \\
\text { Matera }\end{array}$ & $\begin{array}{l}\text { P. pseudoalcaligenes } \\
\text { (An) }\end{array}$ & $\begin{array}{l}\text { Mortar and } \\
\text { alginate } \\
\text { beads }\end{array}$ & $\begin{array}{l}\text { May et al. } \\
(2008)\end{array}$ \\
\hline $\begin{array}{l}\text { Nitrates and } \\
\text { Sulfates }\end{array}$ & $\begin{array}{l}\text { Sandstone walls, } \\
\text { Matera }\end{array}$ & $\begin{array}{l}\text { P. pseudoalcaligenes } \\
\text { (Ae) } \\
\text { D. vulgaris (An) }\end{array}$ & Carbogel & $\begin{array}{l}\text { Alfano et al. } \\
\text { (2011) }\end{array}$ \\
\hline $\begin{array}{l}\text { Calcium sul- } \\
\text { fate and } \\
\text { carbonate }\end{array}$ & $\begin{array}{l}\text { Casina Farnese wall } \\
\text { paintings } \\
\text { (Palatine Hill, Rome) }\end{array}$ & $\begin{array}{l}\text { Cellulosimicrobium } \\
\text { cellulans }(\mathrm{Ae})\end{array}$ & Laponite & $\begin{array}{l}\text { Mazzoni } \\
\text { et al. (2014) }\end{array}$ \\
\hline $\begin{array}{l}\text { Saline } \\
\text { efflorescence }\end{array}$ & Frescoes, Valencia & $\begin{array}{l}\text { P. stutzeri DSMZ } \\
5190(\mathrm{Ae})\end{array}$ & $\begin{array}{l}\text { Cotton wool } \\
\text { Agar }\end{array}$ & $\begin{array}{l}\text { Bosch-Roig } \\
\text { et al. (2010, } \\
\text { 2012, 2013) }\end{array}$ \\
\hline Efflorescence & $\begin{array}{l}\text { Archaeological } \\
\text { frescoes, ceramic and } \\
\text { bones }\end{array}$ & $\begin{array}{l}\text { P. stutzeri DSMZ } \\
5190(\mathrm{Ae})\end{array}$ & Agar & $\begin{array}{l}\text { Martín } \\
\text { Ortega } \\
(2015)\end{array}$ \\
\hline
\end{tabular}

Ae Aerobic metabolism, An Anaerobic metabolism

sulfates and nitrates from $\mathrm{CH}$ stoneworks being able to reduce, in anaerobic conditions, sulfates to $\mathrm{H}_{2} \mathrm{~S}$ and nitrates to $\mathrm{N}_{2}$, respectively.

In the case of the sulfate-reducing bacteria, the mechanism of action occurs through gypsum dissociation into $\mathrm{Ca}^{2+}$ and $\mathrm{SO}_{4}{ }^{2-}$ ions where the sulfates are 
Table 12.2 a and b Prokaryotes organisms involved in sulfur and nitrogen cycles and reported

\begin{tabular}{|c|c|c|c|}
\hline Processes & Reactions & Microorganisms & $\begin{array}{l}\text { Metabolic } \\
\text { pathways }\end{array}$ \\
\hline $\begin{array}{l}\text { Nitrification } \\
{\left[\mathrm{NH}_{4}^{+} \rightarrow \mathrm{NO}_{3}{ }^{-}\right]}\end{array}$ & $\begin{array}{l}{\left[\mathrm{NH}_{4}^{+} \rightarrow \mathrm{NO}_{2}^{-}\right]} \\
{\left[\mathrm{NO}_{2}^{-} \rightarrow \mathrm{NO}_{3}^{-}\right]}\end{array}$ & Nitrosomonas Nitrobacter & Aerobic Aerobic \\
\hline Nitrate reduction & {$\left[\mathrm{NO}_{3}{ }^{-} \rightarrow \mathrm{N}_{2}\right]$} & Bacillus, Pseudomonas & Anaerobic \\
\hline $\mathrm{N}_{2}-$ fixation & Free-living cells & Azotobacter & Aerobic \\
\hline \multirow{2}{*}{$\begin{array}{l}{\left[\mathrm{N}_{2}+8 \mathrm{H}^{+} \rightarrow \mathrm{NH}_{3}+\right.} \\
\left.\mathrm{H}_{2}\right]\end{array}$} & & Clostridium & Anaerobic \\
\hline & Symbiotic cells & Rhizobium, Frankia & Anoxic \\
\hline Ammonification & {$\left[\right.$ Organic-N $\left.\rightarrow \mathrm{NH}_{4}^{+}\right]$} & Several microorganisms & Anaerobic \\
\hline $\begin{array}{l}\text { Ammonium } \\
\text { oxidation }\end{array}$ & $\begin{array}{l}{\left[\mathrm{NH}_{4}{ }^{+} \mathrm{NO}_{2}{ }^{-} \rightarrow \mathrm{N}_{2}\right.} \\
\left.+2 \mathrm{H}_{2} \mathrm{O}\right]\end{array}$ & $\begin{array}{l}\text { Brocadia, Kuenenia, } \\
\text { Scalindua }\end{array}$ & Anaerobic \\
\hline Processes & Reactions & Microorganisms & $\begin{array}{l}\text { Metabolic } \\
\text { pathways }\end{array}$ \\
\hline Sulfate reduction & {$\left[\mathrm{SO}_{4}{ }^{2-} \rightarrow \mathrm{H}_{2} \mathrm{~S}\right]$} & $\begin{array}{l}\text { Desulfovibrio, } \\
\text { Desulfobacter }\end{array}$ & Anaerobic \\
\hline Sulfur reduction & {$\left[\mathrm{S}^{0} \rightarrow \mathrm{H}_{2} \mathrm{~S}\right]$} & $\begin{array}{l}\text { Desulforomonas, } \\
\text { Extreme thermophilic } \\
\text { Archaea }\end{array}$ & Anaerobic \\
\hline \multirow[t]{2}{*}{$\begin{array}{l}\text { Sulfide/sulfur } \\
\text { oxidation }\end{array}$} & {$\left[\mathrm{H}_{2} \mathrm{~S} \rightarrow \mathrm{S}^{0} \rightarrow \mathrm{SO}_{4}{ }^{2-}\right]$} & $\begin{array}{l}\text { Thiobacillus, Beggiatoa, } \\
\text { others }\end{array}$ & Aerobic \\
\hline & & $\begin{array}{l}\text { Phototrophic bacteria (pur- } \\
\text { ple and green), } \\
\text { chemolithotrophs }\end{array}$ & Anaerobic \\
\hline Organic S ox/red & {$\left[\mathrm{Org}-\mathrm{S} \rightarrow \mathrm{H}_{2} \mathrm{~S}\right]$} & Several microorganisms & $\begin{array}{l}\text { Aerobic/ } \\
\text { Anaerobic }\end{array}$ \\
\hline
\end{tabular}

reduced by the bacteria into $\mathrm{S}$, and the $\mathrm{Ca}^{2+}$ ions react with $\mathrm{CO}_{2}$ to originate new calcite, following this reaction:

$$
6 \mathrm{CaSO}_{4}+4 \mathrm{H}_{2} \mathrm{O}+6 \mathrm{CO}_{2} \rightarrow 6 \mathrm{CaCO}_{3}+4 \mathrm{H}_{2} \mathrm{~S}+11 \mathrm{O}_{2}+2 \mathrm{~S}
$$

With regard to the use of these bacteria for the removal of black crusts and sulfates, the first applied studies were performed by immersion of marble fragments in broth anaerobic cultures of strains of Desulfovibrio desulfuricans and Desulfovibrio vulgaris, for a period of 60-84 hours obtaining a removal efficiency of 40-100\% (Gauri et al. 1989, 1992; Heselmeyer et al. 1991).

After these studies, it has been recognized that the immersion technique in liquid culture can have many limitations for large, fragile artworks; therefore, in order to reduce the water absorption to stone due to this methodology, the use of a delivery system has been considered in the successive studies. For this reason, biotreatments have been performed, always in anaerobic conditions, using an inorganic delivery system such as sepiolite colonized with $D$. desulfuricans and/or $D$. vulgaris for the removal of sulfates. Lab-scale tests were carried out both using artificial enriched specimens and real altered stone fragments; these studies evidenced the possibility of obtaining a relevant sulfate removal percentage (around 80\%) in a short period of time (36 hours) (Ranalli et al. 1996, 1997). Sepiolite was also tested for the removal 
of nitrates on brick-works and calcareous stones (marble and Vicenza-stones) using a Pseudomonas stutzeri strain in anaerobic conditions (Ranalli et al. 1996). However, the use of sepiolite gave in some cases problems of dark precipitates (for the presence of iron in trace) requiring a pre-treatment of the sepiolite to remove the iron. In addition, sepiolite as delivery system did not guarantee the right amount of water for the metabolic activity of bacterial cells during the application on stone surface.

The inorganic delivery system was therefore substituted by an organic carrier named hydrobiogel-97 for the immobilization of $D$. vulgaris subsp. vulgaris ATCC 29579 bacterial cells. The biotreatments were carried out both under lab-scale trials on artificially specimens (different lithotypes) and real altered stoneworks, and in situ trials to remove black crusts present on Candoglia stone at Milan Cathedral, Italy. The in situ bioapplication has been carried out using carbogel (CTS, Vicenza, Italy), covered by a thin film to create microaerophilic condition, and repeated 3 times (15 hours each) giving a removal of $98 \%$ of sulfates. A comparison of the biological methods with a chemical one (using ammonium carbonate and EDTA) was carried out in order to define the results in terms of removal, but also to determine the effects on the stone surface; in this case the biotreatment was very promising (Cappitelli et al. 2006, 2007).

Another case study where the sulfate crust was efficiently biocleaned by D. vulgaris subsp. vulgaris ATCC 29579 and carbogel was the Pietà Rondanini marble base sculpture by Michelangelo Buonarroti (Milan, Italy). In order to eliminate secondary iron black deposits, bacteria were grown in a modified broth medium free of iron. Treatment times were of 24-30 hours in anaerobiosis (Cappitelli et al. 2005).

In another applied studies on altered stone sculptures carried out by Polo et al. (2010) the presence of black crusts and the microbial growth causing discoloration were evidenced on the Demetra and Cronos sculptures, two of 12 stone statues decorating the courtyard of the Buonconsiglio Castle in Trento (Italy). Desulfovibrio vulgaris subsp. vulgaris, grown in DSMZ 63 medium without iron source and carbogel as delivery system, was applied to remove the black crusts but preserved the original stone and the patina noble. The altered surfaces were treated with three 12-hours applications for a total duration of 36 hours. This case study, combining traditional and biomolecular methods, showed that conservators can benefit from an integrated biotechnological approach aimed at the biocleaning of the alterations together with the abatement of biodeteriogens (Polo et al. 2010).

Other positive results involved the colored lithotypes of Florence Cathedral external walls. Green serpentine, red marlstone, and Carrara white marble black crust were biocleaned. This work compared three different cleaning treatments: chemical poultice, laser, and biocleaning. Results shows that the better cleaning method was biocleaning using D. vulgaris subsp. vulgaris ATCC 29579 strain and carbogel as a carrier, but long-time treatments and numerous applications were needed (Gioventù and Lorenzi 2013).

In another recent study, the combination of chemical and biological (arbocel nonionic detergent treatment colonized with $D$. vulgaris subsp. vulgaris) methods allowed efficient cleaning of grey deposits and black crusts on marble columns and 
statues at the Cemetery in Milan, Italy, with a notable reduction in the treatment duration (Troiano et al. 2013).

Carbogel alone together with mortar and alginate beads have been also used on tuff stone walls at Matera Cathedral, Italy, for the removal of both sulfates and nitrates (the latter present at higher concentration) using different microorganisms such as Pseudomonas pseudoalcaligenes and D. vulgaris (May et al. 2008; Alfano et al. 2011).

At Matera Cathedral the main problem arises from the rising of salts from the groundwater rich in nitrates and sulfates causing reduction in cohesion of the tuff stone, loss of materials, and the darkening of the lower external walls. The nitrates originate from the oxidation of various $\mathrm{N}$ organic compounds (including proteins, amino acids, and urea) from bodies buried in the ground when the area was used as a cemetery (until eighteenth century). At the same way, sulfates derived mainly by amino acids such as methionine and cysteine rather than environmental depositions. In addition, chemical analyses detected egg residues as previous consolidant treatments of the tuff surface. The biotreatment was efficient, showing a removal of surface deposits and salt alterations after 24 hours (55\% of the nitrate and $85 \%$ of the sulfate deposits) (Alfano et al. 2011; Rampazzi et al. 2018).

Many of the reported studies were performed during a 3 years EU project named BIOBRUSH project (BIOremediation for Building Restoration of the Urban Stone Heritage). The main aims of the project were the selection of microorganisms and delivery system for the removal of black crusts, sulfates, nitrates and also the possibility of using bio-calcifying bacteria for the stone bio-consolidation (Webster and May 2006; May et al. 2008).

The EU BIOBRUSH project gave the opportunity to perform studies under different scale (lab and in situ experiments) giving promising results and showing the aspects to improve and optimize. For example, in some cases, the delivery systems adopted resulted not appropriate to treat large surface areas or decorative elements.

In another study, the combination of chemical and biological (arbocel nonionic detergent treatment colonized with $D$. vulgaris subsp. vulgaris) methods allowed efficient cleaning of grey deposits and black crusts on marble columns and statues at the Cemetery in Milan, Italy, with a notable reduction in the treatment duration (Troiano et al. 2013).

More recent studies showed the use of improved delivery systems as agar-gel colonized by Pseudomonas stutzeri DSMZ 5190 strain for the removal of salt efflorescence on frescoes on the Santos Juanes Church in Valencia, Spain, as reported in Fig. 12.2 (Bosch-Roig et al. 2010, 2012, 2013) and on archeological frescoes, ceramic, and bones (Martín Ortega 2015).

In the first case, Bosch-Roig et al. (2013) demonstrated that short term (90 min) application of $P$. stutzeri DSMZ 5190 and the use of agar as delivery system provided an efficient cleaning of insoluble nitrate efflorescence deposited on wall painting surfaces confirmed by Ion Chromatography (92\% in nitrate efflorescence reduction). Bosch-Roig et al. (2013) underlined the positive properties of agar supporting the microorganisms as follows: (i) it can provided an adequate water 


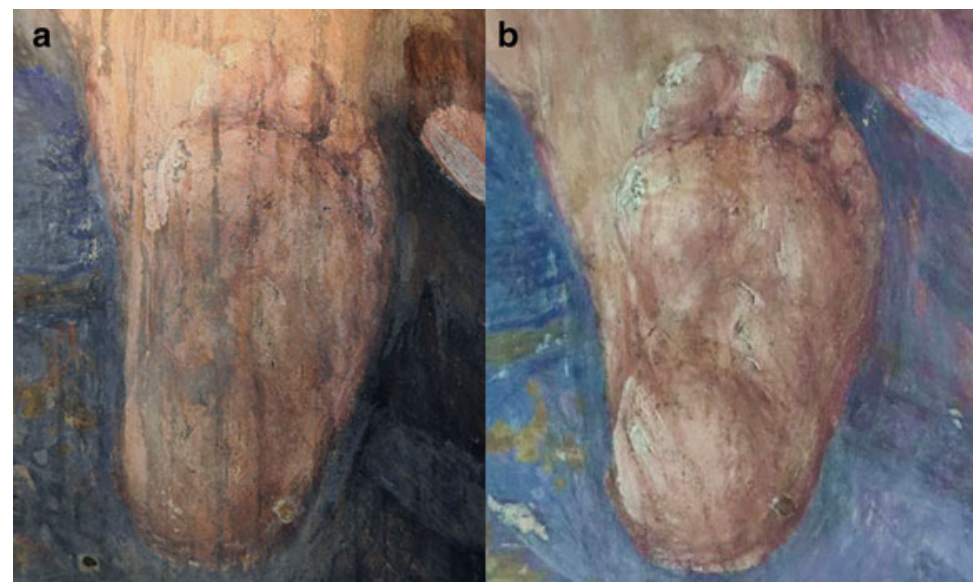

Fig. 12.2 a-b Before (left)/after (right) comparison picture of one detail of the biocleaning of saline efflorescence from the frescos at St. Nicholas church in Valencia, Spain (Gentle concession of the pictures by J.L. Regidor Ros \& P. Bosch-Roig)

supply to the bacterial viability, (ii) can release water only on the surface, in homogeneous and controlled way to avoid damages on the artwork; (iii) absence of stains or residues on the artwork; (iv) easy to apply and remove; (v) non-toxic and eco-friendly. Furthermore, the use of agar is based both on the small volume of water and on shorter time of contact; this means a reduction of risks if compared to others systems that require extended contact periods (Lustrato et al. 2012).

Recently, hydrobiogel-97 colonized with D. vulgaris was also used for the removal of black crusts from weathered stone surfaces in Failaka Island, Kuwait (Elhagrassy and Hakeem 2018).

Laponite colonized with Cellulosimicrobium cellulans was used instead for the removal of calcium sulfate and carbonate at Casina Farnese wall paintings (Palatine Hill, Rome, Italy) as reported by Mazzoni et al. (2014).

Furthermore, advanced biocleaning system using new agar-gauze bacteria gel was carried out at onsite historical wall paintings (Ranalli et al. 2019).

A recent study reports the use of agar-gel colonized with extremophilic bacteria (Halomonas campaniensis) for the biocleaning of nitrate crusts from stoneworks (Romano et al. 2019).

\section{Conclusions}

Numerous studies have been carried out in order to optimize the biocleaning strategies in terms of microorganism efficiency and delivery systems able to maintain and guarantee the microbial activity and ready to be used also on difficult altered stone surfaces (ornamented, vertical, and vaulted). Different substances can be 


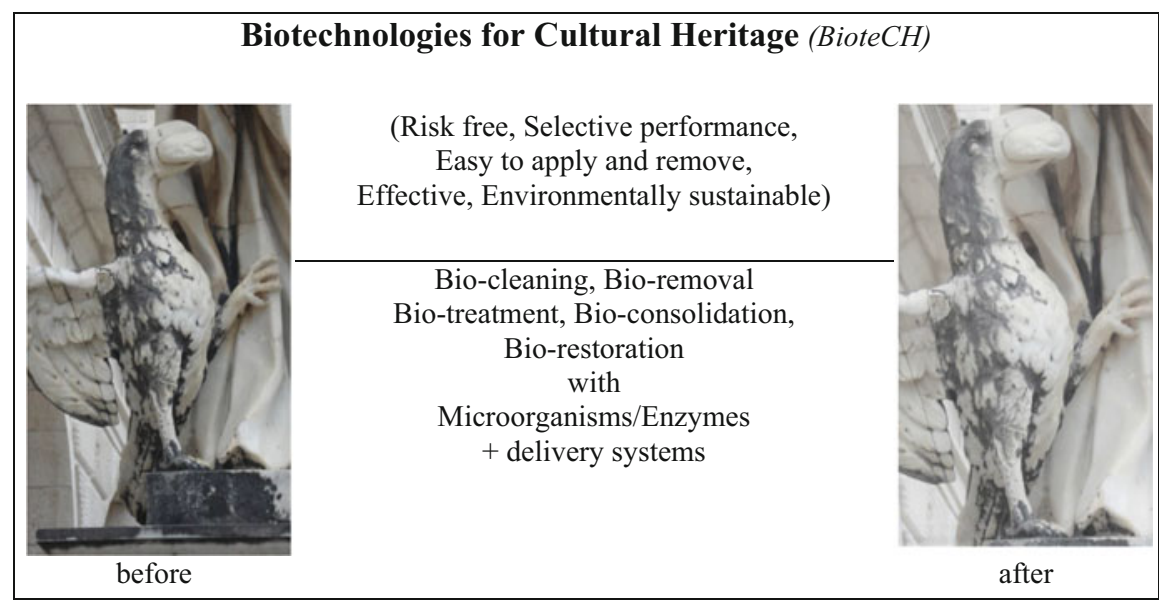

Fig. 12.3 Advantages and strengths of biotechnologies for Cultural Heritage (BioteCH) based on the use of selected microorganisms (before and after comparison pictures of the biocleaning of black crusts on one detail of statue St. Benedetto, at Montecassino Abbey, Italy (Pontone 2014)

present as stone alterations and for this reason, the choice of the best microorganism is a crucial step in the biocleaning technology.

Microbial diversity includes Bacteria, Archaea, and Eukarya (prokaryotic and eukaryotic cells) able to live and adapt to different natural habitats (soil, rocks, hot springs, oceans, etc.), to perform a wide range of metabolic strategies in terms of energy and carbon sources, in presence/absence of oxygen (aerobic and anaerobic conditions) and using light for their photometabolism.

Therefore, a careful selection of the most performant microorganism in the removal of the undesired substances present on stone surfaces as deposits and crusts (in this case mainly represented by salts such as nitrates and sulfates) is the first step in the biorestoration strategies.

The application of the selected microorganism is also important since the carrier, used to apply the viable cells on the altered stone surfaces, must have specific properties and provide them an adequate microenvironment to optimize their activity.

The ideal delivery system should have the following characteristics: (i) able to guarantee the appropriate water content for the microbial activity; (ii) not toxic both for the microorganisms and for the environment; (iii) do not cause any color variation to the stone surface; (iv) applicable to all types of surfaces (horizontal, vertical, oblique, vaulted, rough, smooth, etc.), and finally, (v) easy to prepare and also to apply and to remove at the end of the treatment.

All these aspects about the carrier properties and characteristics were evaluated in a review in order to individualize the best choice for the different situations (BoschRoig et al. 2015). 
The biocleaning process also requires a deep diagnostic study of the work of art to be cleaned, an assessment of any associated risks, an evaluation of the effectiveness and efficiency of the process, and last but not least, an evaluation in terms of economic and environmental sustainability (Bosch-Roig and Ranalli 2014) (Fig. 12.3).

Acknowledgements The authors wish to thank to the restorers involved in the before mentioned case studies because without their confidence, help, and dedication none of this works could have been successfully applied on real artworks. Special thanks to Claudia Sorlini, Maria Perla Colombini, Alessia Andreotti, Laura Rampazzi and Cristina Corti for the continuous collaborations and support in the chemical aspects in our studies on $\mathrm{CH}$ biotechnologies. Special thanks to Arch. B. Lafratta, Superintendence for Restoration, The Technical and Scientific Committee (Matera, Italy); Mons. D. Lionetti, ArciDiocesi di Matera-Irsina; Restorer G. D'Alessandro, Impresa D'Alessandro Restauri, Matera, Italy. Moreover, we are very grateful to the Veneranda Fabbrica del Duomo for assistance and support of the diagnostic work on the Milan Cathedral (Milan, Italy).

\section{References}

Abeliovich A (2006) The nitrite-oxidising bacteria. In: Dworkin M, Falkow S, Rosenberg E, Schleifer K-H, Stackebrandt E (eds) The prokaryotes. Springer, New York, pp 861-871

Alfano G, Lustrato G, Belli C, Zanardini E, Cappitelli F, Mello E, Sorlini C, Ranalli G (2011) The bioremoval of nitrate and sulfate alterations on artistic stonework: the case-study of Matera cathedral after six years from the treatment. Int Biodeterior Biodegradation 65:1004-1011

Atlas RM, Chowdhury AN, Gauri KL (1988) Microbial calcification of gypsum-rock and sulfated marble. J Stud Conserv 33:149-153

Barbabietola N, Tasso F, Grimaldi M, Alisi C, Chiavarini S, Marconi P, Perito B, Sprocati AR (2012) Microbe-based technology for a novel approach to conservation and restoration. EAI Speciale II. Knowledge, diagnostics and preservation of cultural heritage, pp. 69-76

Bellucci R, Cremonesi P, Pignagnoli G (1999) A preliminary note on the use of enzymes in conservation: the removal of aged acrylic resin coatings with lipase. Stud Conserv 44:278-281

Bhatnagar P, Khan AA, Jain SK, Rai MK (2010) Biodeterioration of archaeological monuments and approach for restoration. In: Jain SK, Khan AA, Rai MK (eds) Geomicrobiology. CRC Press, Enfield, pp 255-302

Biavati B, Sorlini C (2008) Microbiologia agroambientale. Ambrosiana, Milano, p 684

Boquet E, Boronat A, Ramos-Cormenzana A (1973) Production of calcite (calcium carbonate) crystals by soil bacteria is a general phenomenon. Nature 246:527-528

Bosch-Roig P, Lustrato G, Zanardini E, Ranalli G (2015) Biocleaning of cultural heritage stone surfaces and frescoes: which delivery system can be the most appropriate. Ann Microbiol 65:1227-1241

Bosch-Roig P, Montes-Estellés RM, Regidor-Ros JL, Roig Picazo P, Ranalli G (2012) New frontiers in the microbial bio-cleaning of artworks. The Picture Restorer 41:37-41

Bosch-Roig P, Ranalli G (2014) The safety of biocleaning technologies for cultural heritage. Front Microbiol 5:155

Bosch-Roig P, Regidor-Ros JL, Montes-Estellés R (2013) Biocleaning of nitrate alterations on wall paintings by Pseudomonas stutzeri. Int Biodeterior Biodegradation 84:266-274

Bosch-Roig P, Regidor-Ros JL, Soriano-Sancho P, Domenech-Carbo MT, Montes-Estellés RM (2010) Ensayos de biolimpieza con bacterias en pinturas murales. Arché 4-5:115-122 
Brimblecombe P, Grossi CM (2007) Damage to buildings from future climate and pollution. APT Bull 38:13-18

Camuffo D (1998) Microclimate for cultural heritage. Elsevier, Amsterdam, p 415

Caneva G, Nugari MP, Salvadori O (2008) Plant biology for cultural heritage: biodeterioration and conservation. The Getty Conservation Institute, Los Angeles, CA

Cappitelli F, Toniolo L, Sansonetti A, Gulotta D, Ranalli G, Zanardini E, Sorlini C (2007) Advantages of using microbial technology over traditional chemical technology in removal of black crusts from stone surfaces of historical monuments. Appl Environ Microbiol 73:5671-5675

Cappitelli F, Zanardini E, Ranalli G, Mello E, Daffonchio D, Sorlini C (2006) Improved methodology for bioremoval of black crusts on historical stone artworks by use of sulfate-reducing bacteria. Appl Environ Microbiol 72:3733-3737

Cappitelli F, Zanardini E, Toniolo L, Abbruscato P, Ranalli G, Sorlini C (2005) Bioconservation of the marble base of the Pietà Rondanini by Michelangelo Buonarroti. Geophys Res Abstr 7:06675-00676

Castanier S, Le Metayer-Levrel G, Orial G, Loubiere JF, Perthuisot JP (2000) Carbonatogenesis and applications to preservation and restoration of historic property. In: Ciferri O, Tiano $\mathrm{P}$, Mastromei G (eds) Of microbes and art. Kluwer Academic/Plenum Publishers, Amsterdam, pp 203-218

Cremonesi P (1999) L'uso degli enzimi nella pulitura di opere policrome. In: Cremonesi P (ed) I Talenti. Il Prato, Padova, pp 5-11

De Belie N, De Graef B, De Muynck W, Dick J, De Windt W, Verstraete W (2005) Biocatalytic processes on concrete: bacterial cleaning and repair. In: 10th DBMC international conference on durability of building materials and components, Lyon, 17-20 April

De Graef B, De Windt W, Dick J, Verstraete W, De Belie N (2005) Cleaning of concrete fouled by lichens with the aid of Thiobacilli. Mater Struct 38:875-882

De Leo F, Iero A, Zammit G, Urzì CE (2012) Chemoorganotrophic bacteria isolated from biodeteriorated surfaces in cave and catacomb. Int J Speleol 41:125-136

De Muynck W, De Belie N, Verstraete W (2010) Microbial carbonate precipitation in construction materials: a review. Ecol Eng 36:118-136

Delgado Rodrigues J, Valero J (2003) A brief note on the elimination of black stains of biological origin. Stud Conserv 48:17-22

Doehne EF, Price CA (2010) Stone conservation: an overview of current research. The Getty Conservation Institute, Los Angeles

Dornieden T, Gorbushina AA, Krumbein WE (2000) Biodecay of cultural heritage as a space/timerelated ecological situation an evaluation of a series of studies. Int Biodeterior Biodegradation 46:261-270

Duthie L, Hyslop E, Kennedy C, Phoenix V, Lee MR (2008) Quantitative assessment of decay mechanisms in Scottish building sandstones. In: Lukaszewicz JW, Niemcewicz P (eds) Proceedings of the 11 th int. congress on deterioration and conservation of stone, Torun, pp. 73-80

Elhagrassy AF, Hakeem A (2018) Comparative study of biological cleaning and laser techniques for conservation of weathered stone in Failaka Island, Kuwait. Sci Cult 4:43-50

EWAGLOS (2016) Weyer A, Roig Picazo P, Pop D, Carras J, Ozkose A, Vallet JM, Srsa I (Eds.). In: EwaGlos-European illustrated glossary of conservation terms for wall paintings and architectural surfaces. English definitions with translations into Bulgarian, Croatian, French, German, Hungarian, Italian, Polish, Romanian, Spanish and Turkish, vol. 17. Michael Imhof Verlag, Petersberg, Germany, pp. 304-307

Fassina V (1994) General criteria for the cleaning of stone: theoretical aspects and methodology of application. In: Zezza F (ed) Stone material in monuments: diagnosis and conservation. Scuola Universitaria C.U.M. Conservazione dei Monumenti, Heraklion, pp 131-138

Ferrer MR, Quevedo-Sarmiento J, Rivadeneira MA, Bejar V, Delgado R, Ramos-Cormenzana A (1988) Calcium carbonate precipitation by two groups of moderately halophilic microorganisms at different temperatures and salt concentrations. Curr Microbiol 17:221-227 
Gauri KL, Chowdhury AN, Kulshreshtha NP, Punuru AR (1989) The sulfation of marble and the treatment of gypsum crusts. Stud Conserv 34:201-206

Gauri KL, Parks L, Jaynes J, Atlas R (1992) Removal of sulfated-crust from marble using sulfatereducing bacteria. In: Proceedings of the int. conference on stone cleaning and the nature, soiling and decay mechanisms of stone, Edinburgh, 14-16 April, pp. 160-165

Gioventù E, Lorenzi P (2013) Bio-removal of black crust from marble surface: comparison with traditional methodologies and application on a sculpture from the Florence's English cemetery. Procedia Chem 8:123-129

Gioventù E, Lorenzi PF, Villa F, Sorlini C, Rizzi M, Cagnini A, Griffo A, Cappitelli F (2011) Comparing the bioremoval of black crusts on colored artistic lithotypes of the Cathedral of Florence with chemical and laser treatment. Int Biodeterior Biodegradation 65:832-839

Gorbushina AA (2007) Life on the rocks. Environ Microbiol 9:1613-1631

Grossi CM, Brimblecombe B, Esbert RM, Alsono FJ (2007) Color changes in architectural limestone from pollution and cleaning. Color Res Appl 32:320-331

Gulotta D, Saviello D, Gherardi F, Toniolo L, Anzani M, Rabbolini A, Goidanich S (2014) Setup of a sustainable indoor cleaning methodology for the sculpted stone surfaces of the Duomo of Milan. Heritage Science 2:6-19

Herrera LK, Videla HA (2009) Surface analysis and materials characterization for the study of biodeterioration and weathering effects on cultural property. Int Biodeterior Biodegradation 63:813-822

Heselmeyer K, Fischer U, Krumbein KE, Warscheid T (1991) Application of Desulfovibrio vulgaris for the bioconversion of rock gypsum crusts into calcite. BIOforum 1(/2):89

Junier P, Joseph E (2017) Microbial biotechnology approaches to mitigating the deterioration of construction and heritage materials. Microb Biotechnol 10:1145-1148

Lustrato G, Alfano G, Andreotti A, Colombini MP, Ranalli G (2012) Fast biocleaning of mediaeval frescoes using viable bacterial cells. Int Biodeterior Biodegrad 69:51-61

Maier RM, Pepper I, Gerba CP (2000) Environmental microbiology. Elsevier, San Diego, p 585

Mansch R, Bock E (1998) Biodeterioration of natural stone with special reference to nitrifying bacteria. Biodegradation 9:47-64

Martín Ortega S (2015) Neteges raonades: Experimentació amb nou tractaments de neteja aplicats sobre 6 peces de material arqueologic divers. Treball final de grau, ESCRBCC, Barcelona

May E (2010) Stone biodeterioration. In: Mitchell R, McNamara CJ (eds) Cultural heritage microbiology: fundamental studies in conservation science. ASM Press, Washington, DC, pp 1-39

May E, Webster AM, Inkpen R, Zamarreno D, Kuever J, Rudolph C, Warcheid T, Sorlini C, Cappitelli F, Zanardini E, Ranalli G, Kgrage L, Vgenopoulos A, Katsinis D, Mello E, Malagodi M (2008) The BIOBRUSH project for bioremediation of heritage stone. In: May E, Jones M, Mitchell J (eds) Heritage microbiology and science. Microbes, monuments and maritime materials. RCS Publishing, Cambridge, pp 76-93

Mazzoni M, Alisi C, Tasso F, Cecchini A, Marconi P, Sprocati AR (2014) Laponite micro-packs for the selective cleaning of multiple coherent deposits on wall paintings: the case study of Casina Farnese on the Palatine Hill (Rome-Italy). Int Biodeterior Biodegradation 94:1-11

McNamara CJ, Mitchell R (2005) Microbial deterioration of historic stone. Front Ecol Environ 3:445-451

Orial G, Castanier S, Le Métayer G, Loubiere JF (1992) The biomineralisation: a new process to protect calcareous stone applied to historic monuments. In: Toishi K, Arai H, Kenjo T, Yamano $\mathrm{K}$ (eds) Proceedings of 2nd int. conference on biodeterioration of cultural property, Yokohama, pp. $98-116$

Ortega-Calvo JJ, Arino X, Hernandez-Marine M, Saiz-Jimenez C (1995) Factors affecting the weathering and colonisation of monuments by phototrophic microorganisms. Sci Total Environ 167:329-341

Pinna D, Salvadori O (2008) Biodeterioration processes in relation to cultural heritage materials. Stone and related materials. In: Caneva G, Nugari MP, Salvatori O (eds) Plant biology for cultural heritage. Biodeterioration and conservation. Getty Publications, Los Angeles, pp $128-149$ 
Polo A, Cappitelli F, Brusetti L, Principi P, Villa F, Giacomucci L, Ranalli G, Sorlini C (2010) Feasibility of removing surface deposits on stone using biological and chemical remediation methods. Microb Ecol 60:1-14

Pontone M (2014) Biorestauro: applicazione di batteri alle opere d'arte - Il caso dell'abbazia di Montecassino. Thesis biology degree, University of Molise, Italy

Ramirez JL, Santana MA, Galindo-Castro I, Gonzalez A (2005) The role of biotechnology in art preservation. Trends Biotechnol 23:584-588

Rampazzi L, Andreotti A, Bressan M, Colombini MP, Corti C, Cuzman O, D'Alessandro N, Liberatore L, Palombi L, Raimondi V, Sacchi B, Tiano P, Tonucci L, Vettori S, Zanardini E, Ranalli G (2018) An interdisciplinary approach to a knowledge-based restoration: the dark alteration on the Matera cathedral (Italy). Appl Surf Sci 458:529-539

Ranalli G, Alfano G, Belli C, Lustrato G, Colombini MP, Bonaduce I, Zanardini E, Abbruscato P, Cappitelli F, Sorlini C (2005) Biotechnology applied to cultural heritage: biorestoration of frescoes using viable bacterial cells and enzymes. J Appl Microbiol 98:73-83

Ranalli G, Belli C, Baracchini C, Caponi G, Pacini P, Zanardini E, Sorlini C (2003) Deterioration and bioremediation of frescoes: a case-study. In: Saiz-Jimenez C (ed) Molecular biology and cultural heritage. Balkema Publishers, Lisse, pp 243-246

Ranalli G, Chiavarini M, Guidetti V, Marsala F, Matteini M, Zanardini E, Sorlini C (1996) The use of microorganisms for the removal of nitrates and organic substances on artistic stoneworks. In: Riederer J (ed) Proceedings of the 8th int. congress on deterioration and conservation of stone, Berlin, 30 September-4 October 1996

Ranalli G, Chiavarini M, Guidetti V, Marsala F, Matteini M, Zanardini E, Sorlini C (1997) The use of microorganisms for the removal of sulphates on artistic stoneworks. Int Biodeterior Biodegradation 40:255-261

Ranalli G, Zanardini E, Rampazzi L, Corti C, Andreotti A, Colombini MP, Bosch-Roig P, Lustrato G, Giantomassi C, Zari D (2019) Onsite advanced biocleaning system on historical wall paintings using new agar-gauze bacteria gel. J Appl Microbiol 126:1785-1796

Ranalli G, Zanardini E, Sorlini C (2009) Biodeterioration-including cultural heritage. In: Schaechter M (ed) Encyclopedia of microbiology. Elsevier, Oxford, pp 191-205

Rivadeneyra MA, Delgado R, del Moral A, Ferrer MR, Ramos-Cormenzana A (1994) Precipitation of calcium carbonate by Vibrio spp. from an inland saltern. FEMS Microbiol Ecol 13:197-204

Rivadeneyra MA, Delgado R, Quesada E, Ramos-Cormenzana A (1991) Precipitation of calcium carbonate by Deleya halophila in media containing $\mathrm{NaCl}$ as sole salt. Curr Microbiol 22:185-190

Rodriguez-Navarro C, Rodriguez-Gallego M, Ben Chekroun K, Gonzales-Munoz MT (2000) Carbonate production by Myxococcus xanthus: a possible application to protect/consolidate calcareous stones. In: Proceeding of the int. congress quarry, laboratory, Monument, Pavia, pp. $493-498$

Romano I, Abbate M, Poli A, D’Orazio L (2019) Bio-cleaning of nitrate salt efflorescence on stone samples using extremophilic bacteria. Sci Rep 9:1668

Saiz-Jimenez C (1997) Biodeterioration vs. biodegradation: the role of microorganisms in the removal of pollutants deposited on historic buildings. Int Biodeterior Biodegradation 24:225-232

Saiz-Jimenez C (2001) The biodeterioration of building materials. In: Stoecker J (ed) A practical manual on microbiologically influenced corrosion, vol 2. NACE, Houston, pp 4.1-4.20

Saiz-Jimenez C (2003) Organic pollutants in the built environment and their effect on the microoorganisms. In: Brimblecombe $\mathrm{P}$ (ed) The effects of air pollution on the built environment. Air pollution reviews, vol 2. Imperial College Press, London, pp 183-225

Saiz-Jimenez C (2004) Air pollution and cultural heritage. In: Saiz-Jimenez C (ed) Proceedings of the int. workshop on air pollution and cultural heritage, Balkema, Seville

Salimbeni R, Pini R, Siano S (2003) A variable pulse width Nd: YAG laser for conservation. J Cult Herit 4:72-76 
Salvadori O, Realini M (1996) Characterization of biogenic oxalate films. In: Realini M, Toniolo L (eds) Proceedings of the 2nd int. symposium: the oxalate films in the conservation of works of art, Editream, Milan, pp. 335-351

Sasso S, Miller AZ, Rogerio-Candelera MA, Cubero B, Scrano L, Bufo SA, Saiz-Jimenez C (2015) Non-destructive testing of stone biodeterioration and biocleaning effectiveness. In: Non-destructive and microanalytical techniques in art and cultural heritage. TECHNART 2015. Catania

Scheerer S, Ortega-Morales O, Gaylarde C (2009) Microbial deterioration of stone monuments-an updated overview. Adv Appl Microbiol 66:97-139

Scherer GW (2000) Stress from crystallization of salt pores. In: Fassina V (ed) Proceedings of the 9th int. congress on deterioration and conservation of stone, Elsevier, Amsterdam, pp. 187-194

Sorlini C, Cappitelli F (2008) The application of viable bacteria for the biocleaning of cultural heritage surfaces. Coalition N 15:18-20

Sorlini C, Sacchi M, Ferrari A (1987) Microbiological deterioration of Gambaras' frescos exposed in open at Brescia, Italy. Int Biodeterior 23:167-179

Tiano P, Biagiotti L, Mastromei G (1999) Bacterial bio-mediated calcite precipitation for monumental stone conservation: methods of evaluation. J Microbiol Methods 36:139-145

Tiano P, Cantisani E, Sutherland I, Paget JM (2006) Bioremediated reinforcement of weathered calcareous stones. J Cult Herit 7:49-55

Troiano F, Gulotta D, Balloi A, Polo A, Toniolo L, Lombardi E, Daffonchio D, Sorlini C, Cappitelli F (2013) Successful combination of chemical and biological treatments for the cleaning of stone artworks. Int Biodeterior Biodegradation 85:294-304

Valentini F, Diamanti A, Palleschi G (2010) New bio-cleaning strategies on porous building materials affected by biodeterioration event. Appl Surf Sci 256:6550-6563

Vergès-Belmin V (1996) Towards a definition of common evaluation criteria for the cleaning of porous building materials: a review. Sci Tech Cult Heritage 5:69-83

Viles HA, Moses CA (1998) Experimental production of weathering nanomorphologies on carbonate stone. Q J Eng Geol 31:347-357

Warscheid T, Braams J (2000) Biodeterioration of stone: a review. Int Biodeterior Biodegradation 46:343-368

Webster A, May E (2006) Bioremediation of weathered-building stone surface. Trends Biotechnol $24: 255-260$

Zanardini E, Abbruscato P, Ghedini N, Realini M, Sorlini C (2000) Influence of atmospheric pollutants on the biodeterioration of stone. Int Biodeterior Biodegradation 45:35-42

Zanardini E, May E, Inkpen R, Cappitelli F, Murrell JC, Purdy KJ (2016) Diversity of archaeal and bacterial communities on exfoliated sandstone from Portchester Castle (UK). Int Biodeterior Biodegradation 109:78-87

Zanardini E, May E, Purdy KJ, Murrell JC (2019) Nutrient cycling potential within microbial communities on culturally important stoneworks. Environ Microbiol Rep 11:147-154

Zanardini E, Purdy K, May E, Moussard H, Williams S, Oakley B, Murrell C (2011) Investigation of archaeal and bacterial community structure and functional gene diversity in exfoliated sandstone at Portchester Castle (UK). In: Sterflinger K, Piñar G (eds) Int. Symposium on biodeterioration and biodegradation (IBBS-15), Vienna, September 19-24, p. 90 
Open Access This chapter is licensed under the terms of the Creative Commons Attribution 4.0 International License (http://creativecommons.org/licenses/by/4.0/), which permits use, sharing, adaptation, distribution and reproduction in any medium or format, as long as you give appropriate credit to the original author(s) and the source, provide a link to the Creative Commons license and indicate if changes were made.

The images or other third party material in this chapter are included in the chapter's Creative Commons license, unless indicated otherwise in a credit line to the material. If material is not included in the chapter's Creative Commons license and your intended use is not permitted by statutory regulation or exceeds the permitted use, you will need to obtain permission directly from the copyright holder. 